\title{
LEGAL PROTECTION OF PERSONAL DATA IN THE FUNCTION OF PROTECTION OF HUMAN RIGHTS AND FREEDOMS
}

\author{
Prof. Ass. Dr. Safet krasniqi ${ }^{* 1}$ (iD \\ ${ }^{* 1}$ University " Ukshin Hoti", Prizren, Kosovo \\ DOI: https://doi.org/10.29121/granthaalayah.v8.i10.2020.1785
}

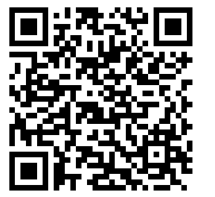

Article Type: Research Article

Article Citation: Prof. Ass. Dr. Safet krasniqi. (2020). LEGAL

PROTECTION OF PERSONAL DATA

IN THE FUNCTION OF PROTECTION

OF HUMAN RIGHTS AND

FREEDOMS. International Journal of

Research -GRANTHAALAYAH,

8(10), 193-197.

https://doi.org/10.29121/granthaa

layah.v8.i10.2020.1785

Received Date: 25 September 2020

Accepted Date: 31 October 2020

Keywords:

EU

Directive DNA

\begin{abstract}
The era of globalization and digitalization have become a necessary process for the legal and legal regulation of human rights. This is taken into account by the fact that technological-technological advances have increased fears of human rights violations. This is especially noteworthy in communication tools, the internet and so on. With the intent, protection of personal data and privacy In the international sphere, the EU has made the coding of the protection of personal data through Directive no. 95/96 EC, which entered into force on 24 October 1995, then the ECHR, the European Commission proposal, January 2012, on the reform of the European Data Protection Regulations, which was formulated in the Regulation which came into force on 24 May, 2016 and the General Directive, which entered into force on May 5, 2016. However, according to surveys made with EU citizens, credibility for the protection of personal data from EU institutions and those of member states is below the minimum. The protection of privacy in Kosovo is being done through the legislation and the establishment of the State Agency for the Protection of Personal Data even though Kosovo does not have sufficient technical and material resources for the minimal protection of personal data and privacy in general. This topic addresses the issue of providing information, the confidentiality of the data subject and the security of proceedings and the supervisory authority. Also, the instructions contained in the regulations, the sanctioning of these rights under the penal code necessarily make the approval of the telecommunications law in Kosovo.
\end{abstract}

\section{INTRODUCTION}

\subsection{METHODOLOGY USED}

The main study method used in the work of this thesis is the traditional method of legal research. It describes international and national legislation, jurisprudence, and legal doctrine.

The main attention is given to domestic legislation, due to the fact that without the analysis of national legislation it is not possible to highlight the problems and to make a further comparison with international standards. To accomplish this research, various study articles and information were used. 
Personal information is any information related to an individual who is known or who can be diagnosed. All personal data does not have the same meaning, but even the same legal protection. some personal data are a particular category of data. Discovery of race, ethnicity, political beliefs, discovery of DNA data, sexual life, etc. Are considered a special category of personal data. The processing of personal data based on the law, their collection for concrete purposes and their preservation no longer than the need to meet the goals, is based on fundamental principles. ${ }^{1}$ With the new technology, it is easy and extremely affordable for anyone to have access to personal data by creating databases for personal data collection and avoidance is almost impossible. This access procedure starts with the registry office through the data on the birth certificate. ID etc. To obtain CVs of other forms that serve for obtaining various documents, banks, participation in various Symposiums and Conferences, various recordings, border control etc. The issue of personal data has long been a priority for both the EU and its, through LegislationDirectives that provide individuals protection in terms of personal data processing and the circulation of such data.

In accordance with these, EU countries are obliged to protect fundamental rights and freedoms with a special emphasis on the processing of personal data entering the privacy domain. Directive 2002/58 / EC of the European Parliament and of the Council of 12 July 2002 relies on the founding treaty of the European Community, and in particular Article 95, requires respect for fundamental human rights and oversight of the principles generally accepted by the Charter of Fundamental Rights of the European Union. The particularity of this legal document is the respect of fundamental rights in accordance with Articles 7 and 8 of the Charter. ${ }^{2}$ Technological-Technological advances are a great source and a great opportunity for data processing. It depends in part on the confidence of users that their privacy will not be compromised. What is worth mentioning here is the legal regulation in each Member State's internal law with a view to protecting the fundamental rights of natural and legal persons, particularly with regard to automatic processing of data pertaining to subscribers and users. Harmonization of legislation should be made in order to avoid obstacles to the international market for electronic communications, etc., through member states $^{3}$. From the aspect of international legal acts under the EU Treaty, it is the Council's decision no.

2008/977 /, dated 27 November 2008 on the protection of personal data processed in the framework of police and judicial cooperation in criminal matters. Within this act is the Hague program for strengthening freedom, security and justice in the EU. ${ }^{4}$ Aimed at cross-border cooperation on law enforcement information in terms of data protection. For this, there is a Council and Commission action plan for implementing this program in terms of ensuring freedom, security and justice in the EU. An important EU document is Directive 95/46 of the European Parliament and of the Council of 24 October 1995 on the Protection of Individuals with regard to the Processing of Personal Data and Free Movement of such Date. This Directive, which departs from the general principles for the protection of human rights and freedoms, and in particular, the respect for privacy, extends the principles enshrined in the Council of Europe Convention of 28 January 1981 for the protection of individuals during the automatic processing of data. ${ }^{5}$ The expression of the will of the data subject is the fundamental condition defined. This will be expressed until it is not limited when processing is necessary for the fulfillment of an obligation relating to the exercise of the public authorization of the controller or of the third party the data are spread. The European Parliament and the Council, on the occasion of the adoption of this Directive, inter alia at item 11 of the entry, have reaffirmed the principles for the protection of the fundamental rights and freedoms of individuals, in particular the respect for the right to privacy contained in this Directive, which Principles, clarify and extend the principles contained in the Council of Europe Convention of 28 January 1981 on the Protection of Individuals with regard to the Automatic Processing of Personal Data. Examples of privacy protection can be obtained from independent public institutes - commissioners on the right to information and Protection of peronal data. The Commissioner's Office tells us what to expect when the Authority of the Commissioner for the Right to Information and Protection of Personal Data (hereafter the KDIMDP) collects our personal data. This applies to the information gathered about the

${ }^{1} \mathrm{http}: / /$ www.bileta.ac.uk/Document\%20Library/1/Data\%20protection\%20 www.e-society.org.mk

2 Directive 2002/58 / EC of the European Parliament and of the Council of 12 July 2002, Article 1. This Directive lays down the processing of personal data and the protection of privacy in the electronic communications sector and is therefore referred to as the Directive on Privacy and Electronic Communications

${ }^{3}$ Yes there, Articles 7 and 8

${ }^{4}$ Council Framework Decision 2008/977 / JHA of 27 November 2008 on the protection of personal data processed in the framework of police and judicial cooperation in criminal matters, Article 4. The decision enters into the framework of acts adopted under the Treaty of EU, Title VI of the EU Treaty

${ }^{5}$ Yes there, Articles, 11

International Journal of Research -GRANTHAALAYAH 
complainant regarding the violation of the data, the various requirements for obtaining information, the people applying for employment, etc.

In spite of all this, the violation of human rights by public institutions or networks of communication in the world continues to be a concern. This is also seen in the various reports of various reporting organizations. According to the projections, in 2016, every 10 American citizen stench was stolen from identity. According to the Javelin Strategy \& Research research agency, 39 percent of stolen identities have been generated through theft of online accounts, with this number rising 3 percent compared to last year. Only in the US, the Federal Trade Commission is contacted by tens of thousands of customers per week declaring identity theft or suspecting they are the victim of these thefts. ${ }^{6}$ When it comes to the issue of identity, we usually have to do with the protection of personal data in terms of their processing by the institutions or agencies of various agencies. This is linked by many factors; eg Collecting information about security threats can have an impact on human rights and fundamental freedoms. According to the 2008 report by the South African Ministerial Commission, in the cases of investigations into the abuses of the National Intelligence Agency, the methods used in the investigations' interventions have played a key role in detecting criminal activities, but at the same time they may be misused to the detriment Of democracy, specifically, in political and social activities and in creating an illegitimate advantage for any politician. ${ }^{7}$. Therefore, the use of covert methods should only be determined by law. This is in line with Article 17 of the International Covenant on Civil and Political Rights stipulating that no one should be subject to arbitrary interference in his private life, family, correspondence, nor should he honor honor and reputation so illegal ${ }^{8}$. The use of hidden interception methods when collecting information from the intelligence service is a limitation of privacy. However, by the definition given by competent persons in the case of South Africa, it can be seen that the restriction of fundamental freedoms can only be justified in cases of national security breaches. These limitations have to pass the test of proportionality and that d.m.th. That the power to collect information should be equated with equally strong guarantees that provide constitutional protection to citizens ${ }^{9}$ Nowadays, a basic tool for data collection is camera surveillance. This way of data collection is done through electronic devices or electronic systems. This way of collecting data also includes the risk of violating Constitutional rights such as; Freedom of assembly, freedom of expression, etc. ${ }^{10}$ The importance of maintaining and analyzing data in economic terms has increased considerably. The world market for video surveillance products up to 2014 is worth $\$ 14$ billion. Such an industry includes an integrated web server (network camera or IP camera) that broadcasts images recorded via LAN or WLAN on a local network or the Internet. An important issue is also the establishment of certain rules for the purpose of protecting the citizens from this misuse. There are court decisions and Council of Europe regulations that are based on general camera surveillance provisions that contain a notice that should be visible and public to enable data subjects to be notified of the measures. The observation system with Camera and recording records should be appropriately protected from unauthorized use. There are no direct camera surveillance provisions in Directive 95/46. It is stipulated that members of the Council of Europe should refer to the ECHR, specifically Article 8, which deals with privacy and family life,

Which is considered to be primary ${ }^{11}$. Directive 95/46 in its text does not include the protection of private data in cases of violation or endangering public order which constitutes the protection of national security. Within the framework of Directive 95/46, the autochthonous processing of personal data by the camera surveillance system is included, but not the simple camera system. In the context of this, it is worth mentioning Kosovo legislation approved by Parliament where as a source have the above-mentioned international legal acts. From reports published by international and local organizations, there is a lack of awareness and knowledge about privacy and privacy. According to the National Endowment for Democracy report, published by the Kosovar Center for Security Studies,

${ }^{6}$ Javelin Strategy Research Avelin Avelin is a consulting firm-based consulting that advises its clients to make smart business decisions in a digital financial world.

${ }^{7}$ Oversight of Intelligence Services, Geneva Centre for Democratic Control of Armed Forces (DCAF), p. 95. DCAF is an

international formation established in 2000 at the initiative of the Swiss Confederation, as the "Geneva Centre for the Democratic Control of Armed Forces". DCAF contributes to strengthening the security sector (SSG) through reforming the security sector (RSS). DCAF's central office is in Basel. Other offices are in Beirut, Brussels, Lubjana, Ramallah and Tunisia.

${ }^{8}$ International Covenant on Civil and Political Rights of 23May 1976, Article 17

${ }^{9}$ Oversight of Intelligence Services, Geneva Centre for Democratic Control of Armed Forces, page, 95-100

10 TAIEX 48527Previous 11 to 15 June 2012, Camera Surveillance Guide, PAGE 2

${ }^{11}$ ECHR article 8. This article establishes the inviolability and respect of private and family life, except in the cases provided for by law 
Legal Protection of Personal Data in The Function of Protection of Human Rights and Freedoms

January, 2015, there is a lack of awareness of the citizens of Kosovo for the protection of personal data. In this report, it is noticed that up to $63.5 \%$ of citizens have stated that they are unaware of their rights regarding privacy and personal data protection. Of this statistic, $44.1 \%$ of respondents lacked absolute information on these rights, while $10.4 \%$ of them know how much, $13.4 \%$ of them are aware to some extent of privacy and personal data. ${ }^{12}$ For this and many personal data related issues is the State Agency for the Protection of Personal Data (ADHDHP) where, among other things, it is the duty to inform the public about the issues and developments in data protection fields. However, from the surveys made below, it is noted for the failure of the DOSPP to inform citizens of their rights to personal data protection. According to the polls, $67.2 \%$ of respondents stated that they are not aware of the existence of this Aggregate as long as $30 \%$ of respondents have knowledge of the existence of this agency. ${ }^{13}$ According to experts on personal data protection in Kosovo, the lack of awareness and the inability to protect personal data is due to lack of measures, lack of sensitization and lack of training despite the fact that legislation has been adopted whereby a good part of It is dedicated to the protection of personal data. It is worth mentioning the Constitution of Kosovo, the Criminal Code of Kosovo, the Kosovo Criminal Procedure Code, the Law on Access to Public Documents, the Law on Electronic Eavesdropping, the Law on the Protection of Informers, etc. The Kosovo Constitution in Article 36 guarantees everyone the right to privacy and protection of personal data. The Law on Personal Data Protection expresses the impartiality of collecting personal data and forbids the overruling of authorizations about their use except in cases when the law provides otherwise. Law on Protection of Personal Data no. 03 / L-172, approved by the Assembly of Kosovo on 29 April 2010, is the basic legal basis for the protection of privacy and data security in Kosovo, based on the main decisions of the EU Directive 95/46 / EC This Law Provides rules that ensure confidentiality, security of proceedings, transfer of records to third countries, legal sanctions etc. ${ }^{14}$ From the Ombudsman's reports in Kosovo, the Agency for Personal Data Protection has reached 100 complaints regarding the violation of privacy as a result of the development of information technology. On the other hand, year 2015 is the year of awareness of the citizens of Kosovo for their rights in privacy namely, the protection of personal data ${ }^{15}$.

\section{I RECOMMEND}

1) Harmonization of laws and regulations in force according to the need and degree of citizens' awareness

2) Improve court efficiency in adjudicating cases that could seriously undermine the reputation of the individual.

3) Protection or provision of informant anonymity and

4) Creating mechanisms through which they could be in step with the technical and technological advances in the protection of human rights and fundamental freedoms or as a preventative tool for avoiding or preventing arbitrariness of state bodies or various electronic networks of private entrepreneurs. This is important for businesses and natural persons to understand their legal obligations.

\section{CONCLUSION}

From the analyzes made and the materials discussed in this paper, the issue of privacy and family rights first in the global plane and then in a more narrower perspective continues to be a challenge not only from the practical but also the normative point of view. From the practical point of view, the inability to effectively protect personal data directly causes a violation of human rights, which jeopardizes the possibility of functioning of the legal system in positive law and also endangers international legal acts. If referring to Kosovo, current legislation is not compatible with institutional options for maximum security of human rights observance because technical and technological advances make it impossible to effectively protect personal data and privacy as a whole. Implementation of the Law on Protection of Personal Data, the Law on Administrative Procedure, and other legal acts should be extended to all sections of the Government. Also, the awareness of citizens about the importance of personal data protection, the cooperation with the State Agency for the Protection of Personal Data by joining the request for the admission of

${ }^{12}$ National Endowment for Democracy, published by Kosovo Centre for Security Studies, January, 2015, page, 7

13 TAIEX 48527Previous 11 to 15 June 2012, Camera Surveillance Guide, PAGE 2 The DAHR was established one year after the adoption of Law no. 03 / L - 172 on Data Protection Personnel in 2010

${ }^{14}$ Law on Protection of Personal Data no. 03 / L-172, approved by the Assembly of Kosovo on 29 April 2010

15 The newspaper 'Kosovo sot', daily, dated, 16.1.2016

International Journal of Research -GRANTHAALAYAH 
new officials are minimal conditions for increasing the efficiency of the protection of personal data, As one of the basic conditions for the protection of human rights and freedoms.

\section{SOURCES OF FUNDING}

This research received no specific grant from any funding agency in the public, commercial, or not-for-profit sectors.

\section{CONFLICT OF INTEREST}

The author have declared that no competing interests exist.

\section{ACKNOWLEDGMENT}

None.

\section{REFERENCES}

[1] http://www.bileta.ac.uk/Document\%20Library/1/Data\%20protection\%20 www.e-society.org.mk

[2] Directive 2002/58 / EC of the European Parliament and of the Council of 12 July 2002, Article 1. This

[3] Directive lays down the processing of personal data and the protection of privacy in the electronic communications sector and is therefore referred to as the Directive on Privacy and Electronic Communications Yes there, Articles 7 and 8

[4] Council Framework Decision 2008/977 / JHA of 27 November 2008 on the protection of personal data processed in the framework of police and judicial cooperation in criminal matters, Article 4. The decision enters into the framework of acts adopted under the Treaty of EU, Title VI of the EU Treaty

[5] Javelin Strategy Research Avelin Avelin is a consulting firm-based consulting that advises its clients to make smart business decisions in a digital financial world

[6] Oversight of Intelligence Services, Geneva Center for Democratic Control of Armed Forces (DCAF), p. 95.

[7] DCAF is an international formation established in 2000 at the initiative of the Swiss Confederation, as the "Geneva Center for the Democratic Control of Armed Forces". DCAF contributes to strengthening the security sector (SSG) through reforming the security sector (RSS). DCAF's central office is in Basel. Other offices are in Beirut, Brussels, Lubiana, Ramallah and Tunisia.

[8] International Covenant on Civil and Political Rights of 23May 1976, Article 17

[9] Oversight of Intelligence Services, Geneva Center for Democratic Control of Armed Forces, page, 95-100

[10] TAIEX 48527Previous 11 to 15 June 2012, Camera Surveillance Guide, PAGE 2

[11] ECHR article 8. This article establishes the inviolability and respect of private and family life, except in the cases provided for by law

[12] National Endowment for Democracy, published by Kosovo Center for Security Studies, January, 2015, page, 7

[13] TAIEX 48527Previous 11 to 15 June 2012, Camera Surveillance Guide, PAGE 2 The DAHR was established one year after the adoption of Law no. 03 / L - 172 on Data Protection Personnel in 2010

[14] Law on Protection of Personal Data no. 03 / L-172, approved by the Assembly of Kosovo on 29 April 2010 the newspaper 'Kosova sot', daily, dated, 16.1.2016 